\title{
Protection masks with religious motifs: COVID-19 produces new religious materiality
}

\author{
Patrícia Rodrigues de Souza ${ }^{1}$ \\ Received: 20 July 2020 / Accepted: 9 September 2020 /Published online: 18 September 2020 \\ (C) Springer Nature Switzerland AG 2020
}

\begin{abstract}
Preventive procedures against COVID-19 pandemic have caused many changes in everyday life's material aspects. Confinement and social distancing have certainly been the most impacting ones. Such condition highlighted that religions, usually taken as something private and transcendent, are actually very material, in the sense that they are made in contact with and through body practices. The interruption of rituals and gatherings for religious activities prompted new religious material forms, like the use of technology for virtual ceremonies and protection masks adorned with religious motifs, the main point of this paper. Masks with Christian and Afro-Brazilian religious motifs sold on the internet as well as the process of making masks for donation as an unexpected form of religious activity will be here investigated. The goal is to show that material forms are intrinsic to religion and when they are suppressed in a way, they come around in another, for people need materiality to make unreal, real. The use of Material Religion approaches to examine such object should reveal that the many changes in religion triggered by pandemic will have occurred not because of the ideas it may evoke but through the material changes it might have occasioned.
\end{abstract}

Keywords COVID-19 and religion - Material Religion andCOVID-19 - Material Religion · Religious studies and COVID-19 · Material culture and COVID-19 · Religion and protection masks

Patrícia Rodrigues de Souza

patsouz@hotmail.com

1 Religious Studies, Pontifical Catholic University, Sao Paulo (PUC SP), São Paulo, Brazil 


\section{Introduction}

If ritual masks ${ }^{1}$ have been traditionally part of some religion's ceremonies, now they are going to be part of them all. The new coronavirus outbreak made masks for individual protection to become an indispensable piece, as well as its symbol, as the following image of the Brazilian artist Eduardo Kobra's mural reflected. In this mural, psychological effects caused by continuous use of masks are softened due to all the elements that compose it - children meaning rebirth, cheerful colors, and religions together (Figs. 1, 2, 3, 4, 5 and 6).

Although COVID'S contamination does not show any visual typical symptom, the constant use of masks on the streets and in other public places has changed big cities' "peoplescape." To be continuously wearing the mask and to be always surrounded by masked people do not let us forget the constant (real or imagined) threat we are under and may trigger feelings of irritation, anxiety, fear, panic, hopelessness. When one merely heard about COVID (but not seeing any sign) it did not make it feel as real, but the constant use of protection masks in everyday life materialized its closeness. To see people wearing masks was something common only in hospitals.

Although Brazil reached the second place in COVID's world ranking, temples and churches were allowed to reopen, even when statistics did not show tendency to decrease. From the beginning of the outbreak, there was no consensus at all among religions, neither agreement within a single religion nor unity within a single congregation, order, or segment of one same religion about the total suspension of religious activities or safety procedures. Priests' attitudes ranged 'from online cults to telling devotees 'don't read any news about pandemic!'” as written by the journalist Leandro Machado (Machado, L 2020) for BBC News Brazil. Religious places which decided to reopen tried to follow some precautionary measures such as reducing the number of people, distancing, cleaning up before rituals and meetings, keeping alcohol gel, measuring temperature, and using masks; the obligation of such measures varied locally. On May 31, evangelicals publicly manifested against the use of masks in the city of Santa Helena, in the state of Maranhão, northeast of Brazil. A huge group of people went on the streets, without any distancing, neither wearing masks, and actually burning them, claiming "Jesus doesn't want to see people hiding in masks. God does not appreciate coward ones." (Pragmatismo Político 2020). On July 3, it was published in the Diário Oficial da União (government's official announcement) under the law number 14.019 the mandatory use of individual masks to circulate in public and private spaces including all kinds of public transportation. However, Brazilian president Jair Bolsonaro vetoed the obligation of its use in state bodies and public institutions, commercial and industrial establishments, religious temples, and other indoor places where people were gathered. Alleging it could incur household violation (Agência do Estado 2020). Brazil is a huge country, and it is impossible to know and control the use of masks, specially out of big cities. Despite apparently local resistance, the Brazilian population seemed to have adhered the use of masks. Walking on the streets and going to parks, shops, markets, or temples, it was rare to see somebody not wearing the mask, at least in the big cities.

\footnotetext{
${ }^{1}$ About religious masks from Material Religion perspective see Roberts, A. F. "Masks" in Plate, B. S. Key Terms in Material Religion, 2015
} 


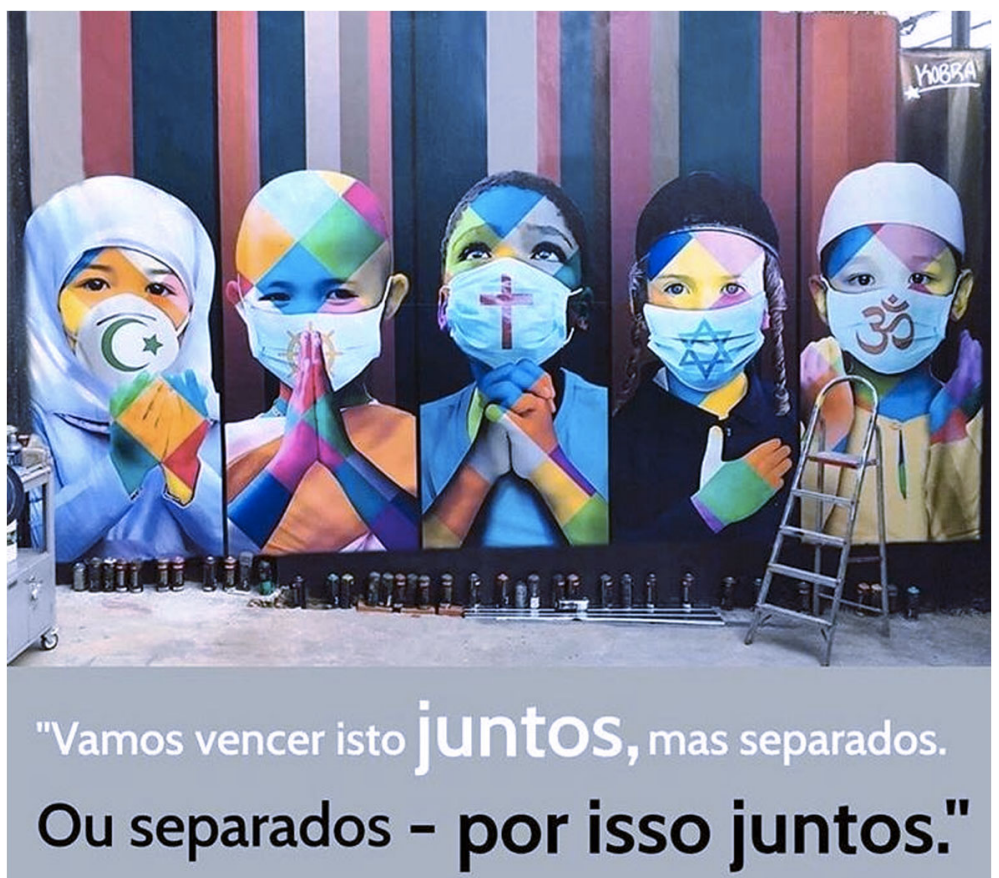

Eduardo Kobra

Fig. 1 Eduardo Kobra's reflection on COVID-19 pandemic: "We'll win this together, but separate. Or separate - because of this, together." Posted on Instagram. Access: 02/07/2020

We don't know whether because the use of masks became mandatory or because people may have felt safe wearing them, but masks turned to be a quotidian accessory and for this reason, as expected, marks of culture started to be imprinted on them, they

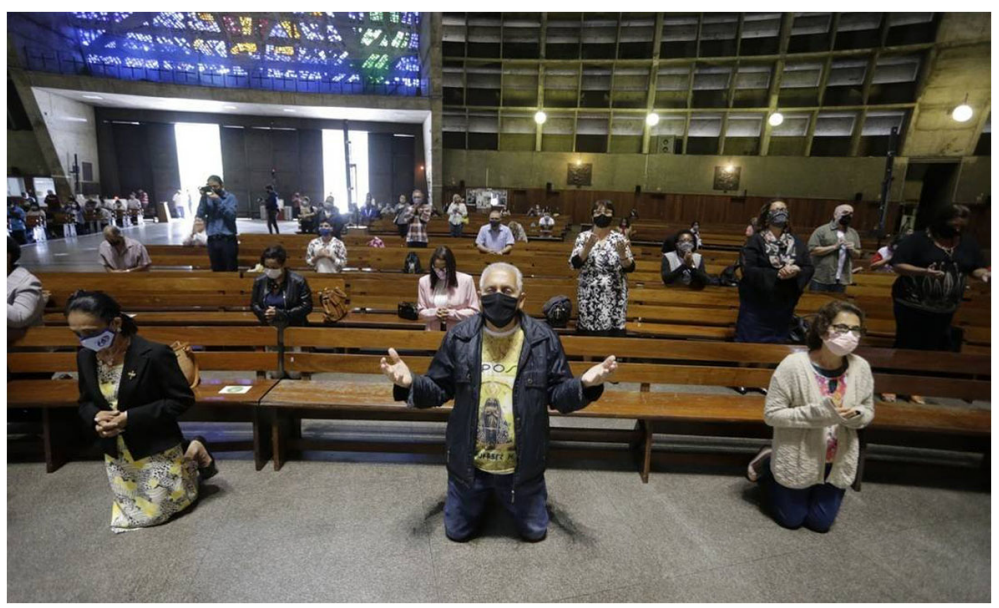

Fig. 2 A church recently reopened in Rio de Janeiro (reproduced from Globo Sociedade). Available at: https:// oglobo.globo.com/sociedade/brasil-tem-63409-mortes-por-covid-19-aponta-consorcio-de-veiculos-deimprensa-no-boletim-das-13h-24515877. Access: 04/07/2020 (Globo Sociedade 2020) 


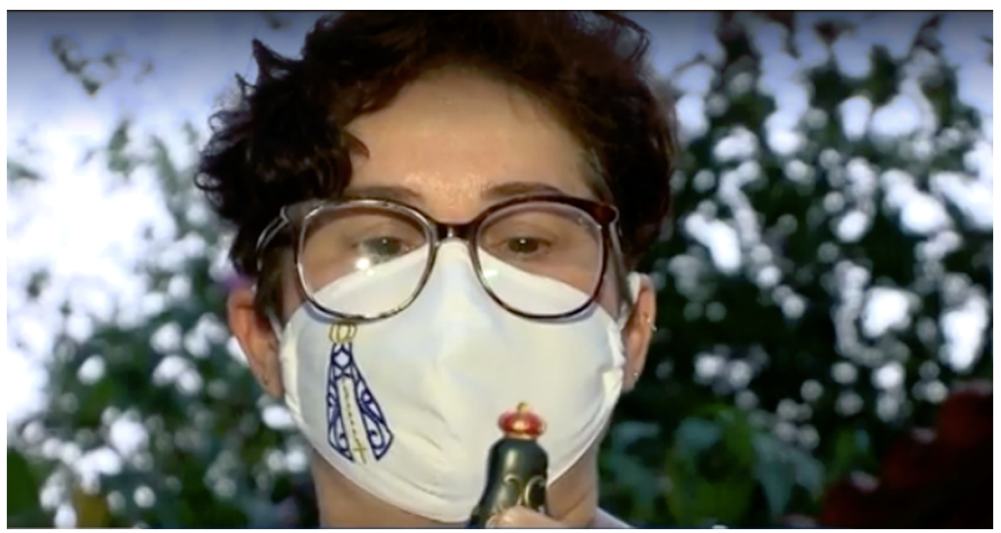

Fig. 3 Nurse Claudiane Sampaio holding Our Lady's image and wearing “Our Lady's mask” (image by Gustavo Cavalcante. Reproduced from Bom Dia Piauí 2020). Available at: https:/globoplay.globo.com/v/ 8537111/. Access: 28/06/2020

would match the lady's outfit - few famous brands such as Chanel, Victor Hugo, Osklen and others designed fashionable and collectable masks - there was also those ones with funny motifs to cheer up children, the professional ones exhibiting the company's logo and its institutional color and masks that announce the soccer fan's team or expresses someone's religious faith. In this paper, I tried to grasp pandemic's impact on religious material aspects and consequently in devotee's religious routines by investigating the commerce of individual protection masks adorned with religious motifs. I particularly analyzed the masks offered on the internet, as well as their production. Nevertheless, what prompted me to write such paper was seeing people on the streets and public places wearing the masks adorned with motifs of their religious preferences.

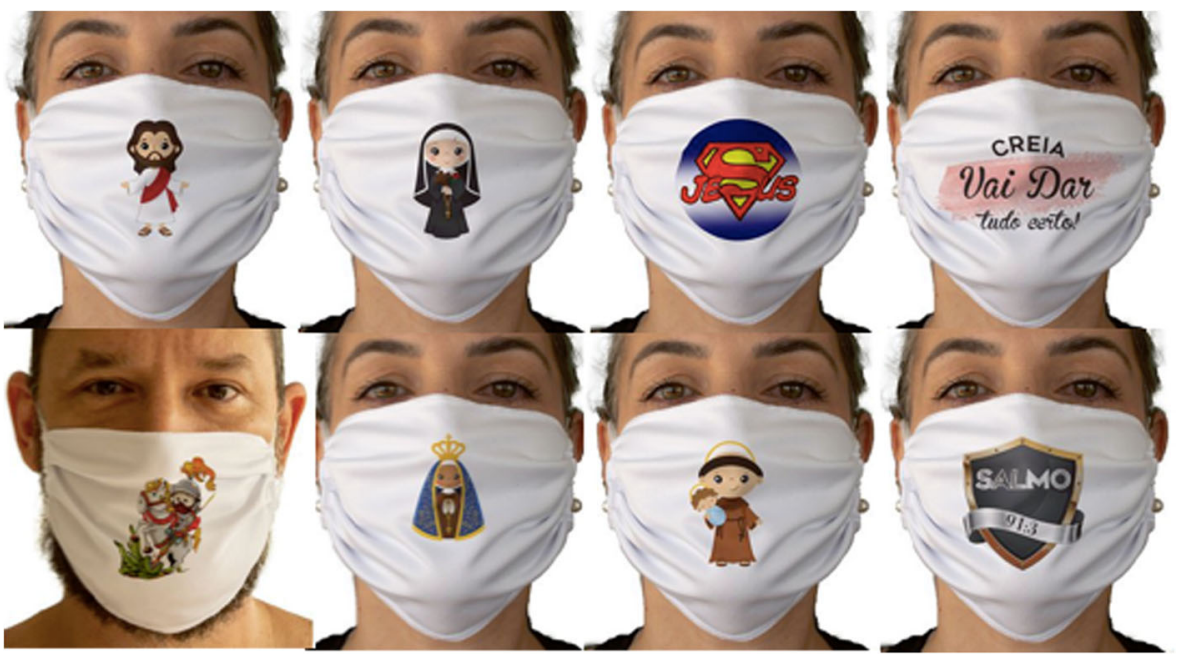

Fig. 4 Masks sold at the virtual shop Máscaras divertidas (Fun masks), religious category (reproduced from mascarasdivertidas.com.br). Available at: https:/www.mascarasdivertidas.com.br/mascaras-tecido-covidestampas-religiosas. Access: 10/07/2020 


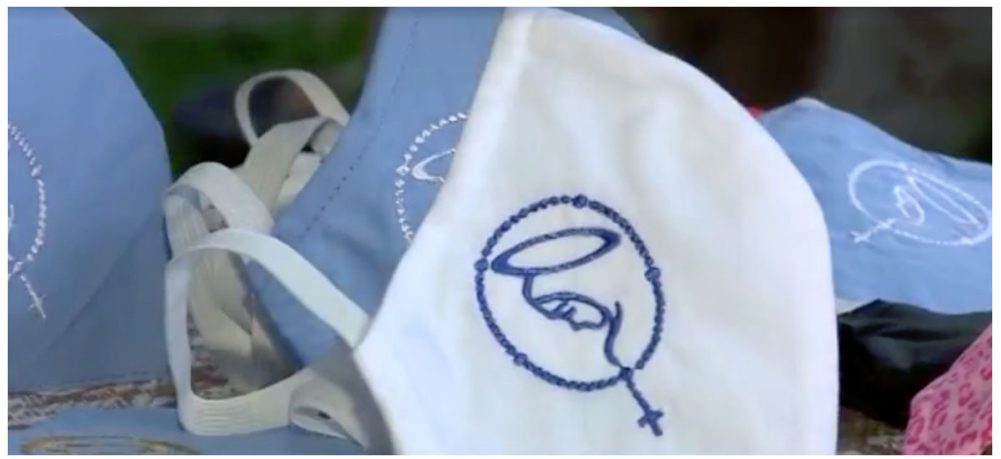

Fig. 5 Colors of Our Lady in the month of May. Protection masks to pay homage to Our Lady are commercialized in Teresina (image by Gustavo Cavalcante. Reproduced from Bom Dia Piauí 2020). Available at: https://globoplay.globo.com/v/8537111/. Access: 28/06/20

\section{COVID's agency vs. religious agency}

Wars and pandemics challenge people's beliefs, values, and practices. "While exposure to the virus may be near ubiquitous, not everyone who is exposed becomes infected. Infectivity, in turn, does not inevitably lead to pathogenicity, to diagnosis with the signs and symptoms of disease. Nor are all clinical cases virulent enough to require medical care, and only a subset of a subset of a subset of those will require hospitalization" (Levin 2020), everyone will be somewhat impaired by COVID's agency —at least emotionally and/or financially. Religion, however, could be a modifier, intensifying or softening COVID's symbolic power by its own agency over people. The pandemic was religiously interpreted in many ways - end of the world, humanity is being punished, God's wakeup call, transition to a new era, etc. These and other interpretations caused people to experiment different feelings: fear of death, fear of not being saved (damnation), distress, guilt, repentance, hopelessness or hope, compassion, faith, etc. For those who may feel any of this, these are very real, displaying religion's agency. How is religion's agency made concrete, if in common sense, religion is believed to happen only through ideas and reflection? We learnt to discard materiality as if it was too

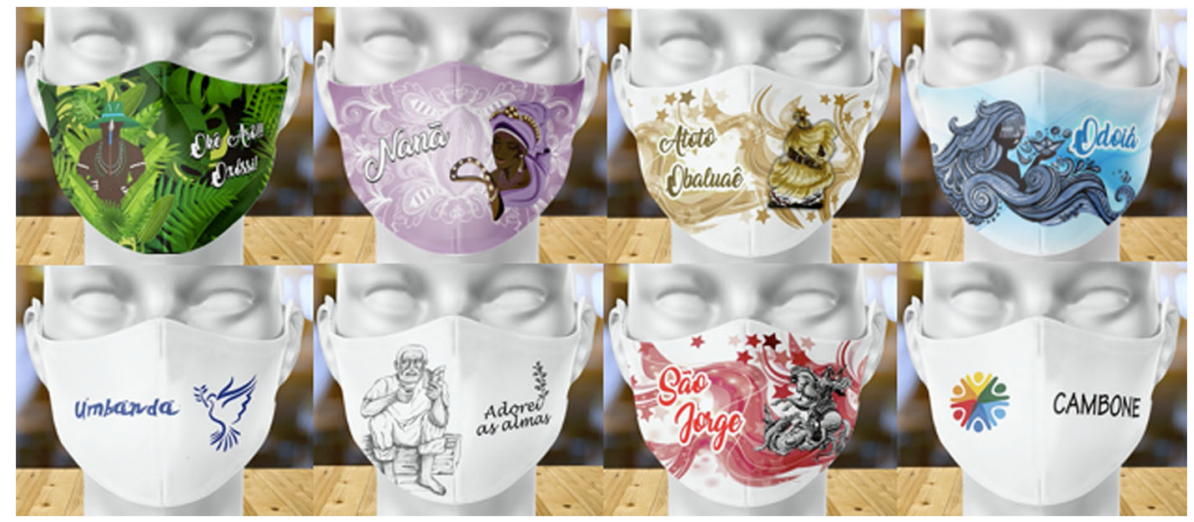

Fig. 6 Masks with Afro-Brazilian motifs (reproduced from website artedosorixas.com.br). Available at: https://www.artedosorixas.com.br/categorias/mascaras-de-protecao. Access: 14/07/2020 
mundane to belong to religious realm (Vasquez 2011; Harvey 2013). But in fact, agency occurs through material means, that is, through whatever is perceived by our senses. Every day we would be loaded with news and social media images of hospitals, sick people, coffins, open graves waiting for corpses and run into people keeping distance, madly washing hands, spraying alcohol, wearing face shields and masks COVID's power was then, materialized through minor daily panicking rituals. About the use of masks, still could be added that most public smiles were covered, and for having half of the face covered, it took us longer to recognize people's emotional reactions, while voices got muffled. Adding color, patterns, symbols, and religious motifs to protection masks may have softened the fact that they unconsciously reminded us all the time: the risk of imminent death.

Alfred Gell defined things as "social agents" (1998: 21), and their influence was as effective and extensive as of a person's. And what was religion's counterpart against COVID's agency? In normal circumstances, against usual threats, devotees would appeal not only to prayers but to praying in their temples (with propitious ambiance), meeting their priests, embracing fellow believers (specially in Brazil), dancing ritual dances, incorporating spirits, sharing communal meals, receiving blessings (from someone's imposed hands), and materializing the comfort and the spiritual protection from whatever or whoever was sacred to them.

What are the best ingredients to produce something 'Real'? To some extent, ideas, concepts, words and symbols are useful but only to the extent that they can be attached to the devotee's body, emotions, practices and material culture. Things, objects and substances must be felt, touched, smelled and grasped by the sensorium, and then transformed into something Real through an imaginary. (Mohan and Warnier 2017: 374)

The pandemic imposed several physical restrictions; quarantine and social distancing were surely the most impacting ones for precluding regular religious practices, undermining religion's agency. The pandemic made material and bodily aspects of religion to stand out. What was then the religious' counterpart in such circumstances?

Reflecting upon religious studies, the pandemic has highlighted issues that Material Religion scholars, since 2005 , have been trying to point out-believing is an activity that involves much more than to be committed to a set of ideas; it implicates the whole body and by extension its relationship with material world. As David Morgan defined it: "Belief is what I know with my body" (Morgan 2010: 9). Therefore, body practices and the influence of objects and spaces in the building of one's religious life (eating, dancing, praying, kneeling, playing music, clothing) should be considered much as textual sources (Meyer 2009; Morgan 2010; Vasquez 2011; Harvey 2013).

In the investigation of the masks, it was fundamental to comprehend the relationship between body and objects. Based on Mauss' original idea of body techniques, objects are understood as extensions of the body, as we also use them to build ourselves (Mauss 2006[1936]). "The subject is a body and has a body" (Mohan and Warnier 2017: 373). Sometimes, the body can be considered an object, in a sense that it is an instrument, and some other times objects are body, as if they were members. Isn't it the case of individual protection masks? And when they had religious motifs imprinted on 
them, would not it have been a form of religious agency, for those who wore it and for those who would see it?

[W] e shall collapse together the techniques of the body and the material culture of religion. All too often they are kept separate. Some academics deal with the body, others with material culture. This division of labor has adverse effects on our understanding of both. All the techniques of the devotee's body are propped against specific material cultures such as those of the temple, shrine, musical instruments, food, drink, clothing, images, sacred objects and substances. We should never talk of material culture per se, except as a kind of shorthand for 'bodily-and-material culture' hyphenated together. (Mohan and Warnier 2017: 373)

The interdependence of material culture and techniques of the body was specially stressed in the use of protection masks with religious motifs, for it is a piece of material culture that went right on the body, making it a body part. Nurse Claudiane Sampaio, had been devoted to Our Lady since she was a child, so for her wearing a mask with Our Lady's image embroidered on it may have felt as a "double protection" - for body and spirit - religion gave it extra agency. She declared: "I never start working without praying to Her, asking for protection."

\section{Religion, contact, and new materiality}

Looking at religion from material perspective, in order to investigate the use of religious masks, another way of thinking about it was through the idea of contact. "Religion has everything to do with the relationships that constitute, form and enliven people in everyday activities in this material world" (Harvey 2013: 2). Religions are made in contact with humans and other-than-human beings - spirits, animals, sacred trees, stones, statues, etc. In any case, contact happens in some sensorial form - sound, touch, vision, taste, smell, or more than one at the same time-according to some Material Religion scholars, a community is a group in which members share such esthetic aspects, that is, they sense or they are formed to sense the world in a similar way (Meyer 2009; Morgan 2010).

Belief is a shared imaginary, a communal set of practices that structure life in powerfully aesthetic terms. Belief is perhaps best framed as a pervasive community of feeling because the holding that it involves is public and verifiable when it consists of holding to other people and the institutions they share. (Morgan 2010: 7)

In religious groups, such verifiability is possible because religions esthetically shape their devotees' esthetic world. This is what anthropologist and Material Religion scholar Birgit Meyer has called esthetic formation:

These processes of forming mold particular subjects through shared imaginations that materialize through embodied aesthetic forms. The term aesthetic formation, then, highlights the convergence of processes of forming subjects and the making 
of communities. In this sense, "aesthetic formation" captures very well the formative impact of a shared aesthetics though which subjects are shaped by tuning their senses, inducing experiences, molding their bodies, and making sense and which materializes in things. (2009: 8, my emphasis)

All religions carry along with their ontologies material forms in order to make them real. One thing is to hear a story (myth, parable) and memorize it; another is to hear a story and learn it within the body - in a way that it becomes an "embodied aesthetic form" (Meyer 2009: 8). For example: in communal meals where specific foods, that could be allowed (considered sacred) or forbidden (considered taboo), were associated to certain mythical or doctrinaire contents, they imprinted the body with axioms-like, through taste and smell. These impressions would later be turned into values - as food sociologist Claude Fischler stated: "socially constructed norms and representations become internalized-inscribed in taste-buds and metabolisms"(1988: 276), in a way that certain foods may feel delicious, nutritious or repugnant.

Some of the aesthetic forms that are so characteristic in shaping devotees and therefore, important for underpinning communities, such as rituals and specific types of contact, were shaken by COVID's agency: contact with spirits through trance, exchanging blessings through hands, shaking hands, kissing hands, embracing, eating together, sharing cups with sacred drinks, pipes, and handling holy wafer; how were these supposed to be done if they were supposed to be done during pandemic?

Apparently, alternative worshippings happened through the development of new materialities, that is, new forms of contact and relationship. Masks promoting some onsite contact and media promoting virtual contact were the main contingent actions. It became very common to see funerals on Facebook, mass and cults on Youtube, spiritual meetings for emanating healing energies on Zoom, spiritual and religious classes on distance education platforms and priests discussing several issues (including pandemic) on live sessions watched by the devotees.

$[\mathrm{M}]$ ost religious groups are innovating in response to opposing demands of collective worship and social distancing. For example, religious communities all over the world are conducting online services, stretching the world's data bandwidth at certain times of the week to stream live videos of suitably modified rituals, sermons, and prayers. (Wildman et al. 2020:116)

Recognizably, the idea of religion in the media is not new; catholic masses, protestant preaches on TV, and Umbanda courses through the internet have been happening for many years. Nevertheless, with new technologies and social medias, the pandemic catalyzed processes that would have naturally happened, but slower. Material Religion scholars had been already making prophecies on the influence of media and mediation in the building of religious agency, as did Birgit Meyer in 2009: "More attention needs to be paid to the role played by things, media, and the body in actual processes of community making" (Meyer 2009: 6). "The making of bonds in modern times depends on media and mediation (Meyer 2009: 6). "Moving beyond a view of religion and media in terms of a puzzling antagonism, in which two ontologically distinct spheres the spiritual and the technological - collide, scholars now develop new approaches that 
regard media as intrinsic to religion" (Meyer 2009: 1). Differently from the use of technology to produce religion, the distanced on-site contact mediated by individual protection equipment was completely unexpected.

Though most religions were forced to consider using technology, each religion already had its own materiality and particular spectrum of contact. Some of them had monks already living confined in monasteries and not having any physical contact with outsiders; some others encouraged solitude and individual practices; these probably did not feel much difference in their everyday practices. In some of the religions that traditionally gather many people inside of a place at once, they do it, for example, to listen to preaches and prayed together. During such rituals, they possibly execute certain body movements, but they don't necessarily need to touch neither stay too close to each other. In such cases adaptations are possible, but certainly, something gets lost when traditional material forms are changed. In some religions there are forms of contacts which might be indispensable, making it more difficult to adjust to such circumstances. Harvey Whitehouse's Modes of Religiosity, 2004, classifies religions into two large groups according to the type of cognition they promotedoctrinal mode and imagistic mode. The former is highly routinized, based on repetitive sermonizing and semantic memory, usually having a formal written doctrine; it is very centralized and presents very little innovation in its rituals as well as a low level of sensorial stimuli. The latter is very little repetitive, highly arousing in terms of sensorial stimulation; it is based on episodic memory (related to personal religious experience, a memorable episode) and usually does not have a formal written doctrine, and it is decentralized.. Evidently, religions do not fit a hundred percent in a mode or another; they may be varying shades of both, but always showing one stronger tendency. It is In order to adapt their ritual routines in times of pandemic, religions that fit into doctrinal mode may have probably found a better use of technology when they tried to convert their on-site rituals to virtual, because for them, sensorial experience was secondary; rituals could be done through media, whereas imagistic mode is dependent on body practices, usually involving physical contact. In this case, although many might have considered it hazardous, it is possible that the majorly imagistic religions kept on doing on-site rituals, though with several adjustments, including safety procedures, where the use of protection masks was one of main measures, since the World Health Organization placed the use of masks as the main resource to prevent contamination. Some people argued that the suspension of regular religious activities, especially those done in group, could be more harmful to people's (mental) health than getting infected by COVID19, as asserted Pentecostal Church leader Silas Malafaia (Terra notícias 2020): "Are people going to die because of coronavirus? Yes. But if there is going to be social chaos, many more will die. Churches are essential to assist people in despair, anguished, depressive, people that are not assisted in hospitals. Also, sociologist Clemir Fernandes from ISER (Religious Studies Institute) reflected on the existence of small Pentecostal churches (something very common in Brazil): "A person goes to the supermarket, where there are more people than in the church located at his/her street's corner. And, in that church, this person does not feel insecure... People protect themselves; they are not irresponsible" (Terra notícias 2020).

\section{Religious masks}

Whether to go to religious rituals or to the supermarket, devotees found an alternative way to materialize their beliefs: adorning individual protection masks with images of 
entities to whom they were devoted. In most places the use of masks became mandatory, but wearing the mask also would produce a feeling of protection which was supported by science (considered by many as unquestionably truthful) and possibly reinforced when associated to the devotee's religion's symbol. Either because it really worked or because the safety sense it would evoke, much of the on-site contact were happening justified upon the effectiveness of masks.

As soon as World Health Organization declared masks as the most effective measure to prevent contamination, the use of chirurgical disposable masks was quickly difused; as the pandemic got worse, more people adhered to using masks, to the point that it started lacking by the end of March. That made the Ministry of Health to test and approve, in April, reusable masks of fabric so that the disposable ones could be destined only to health professionals.

Brazilian economy is known for its informal markets and street vendors, they quickly responded the demand for masks, by producing ("homemade") and selling large amounts of assorted fabric protection masks - white, black, patterned, and with different textures of fabric - offering different types, especially in colors, which certainly stimulated people to have several. People choose and change their clothes only for hygienic and climate purposes, they also choose one piece instead of another, according to their moods, tastes and conceptions. With such diversity and availability of fabric masks, people started choosing them probably, the same way they did about their clothes, especially because masks go where we they most looked at - the face - may be an object to be part in the building of self-identities. The time for pandemic to end is uncertain; the news even talked about a second wave. It is possible that masks would be still worn for a while and, as time passed, its use would become less odd and more natural. If they would be worn for a long time, its first purpose - prevention against COVID — could be "forgotten"; masks would work as a display for identity, ideologies, and beliefs. In this case, masks could be, somewhat, comparable with t-shirts. Their main function was to cover the body, but it has long become a display for ideas and identities.

In the photo above, masks do resemble T-shits prints. They presented behind them a Christian, possibly a Catholic. It was probable that although motifs were Christian, Protestants would not wear anything with images, fearing incur into idolatry. Clearly, this manufacturer's design wished not only to evoke faith but also to spread messages of joy and hope, through the childish style of its figures, such as the cute Jesus and cute little nun on top, from left to right, followed by written Jesus, using the " $\mathrm{S}$ " of Super Man's symbol. The fourth mask says: "Believe it. Everything is going to work out." At the bottom: Saint George, the holy warrior; Our Lady and Saint Anthony, respectively - three of the most popular saints in Brazil. And the fourth indicates "Psalm 91:3" in the Bible: "Surely He will save you from fowler's snare and from deadly pestilence." I picked just 8 samples to give an idea, but this particular manufacturer offered 23 different religious motifs, all Catholics.

An interesting case of religious masks happened in the month of May, Mary's month; in order to pay her homage, dressmaker Alexandra França together with Joice Farias, who has a company that does embroidery, both from Teresina (northeast of Brazil), started producing masks with Our Lady's image embroidered on them. Alexandra said "we had this idea thinking of people of our own families, whom spend this month, wearing either white or light blue to pay homage to Our Lady. I was thinking on my own aunts and cousins and, then, orders started to come up" (Bom Dia Piauí 2020). 
For Joice Farias, as for other people, producing masks, an unexpected business, helped to make income, compensating the decreasing of work caused by pandemic (Bom Dia Piauí 2020). In São Paulo, street vendors could be seen in the corners, close to supermarkets or drugstores selling out handmade fabric masks, possibly for not making their regular income or for having lost their jobs due to pandemic.

The following figure shows masks from a manufacturer specialized in AfroBrazilian religions - Candomblé, Umbanda, Catimbó, Almas e Angola, Jurema, Xangô, Tambor de Mina, Terecô, Batuque, and many others. All such religions present many variations, but African deities play, if not a central, at least a very important role in all of them; those are called orixás; they are related to nature forces and elementsmetals, thunder, fire, sea, rain, waterfalls, rivers, trees, leaves, earth, and grains - as well as to human activities and values, metallurgy, hunting, mothering, war, justice, peace, prosperity, fertility, love, etc. In such religions, each devotee is supposed to be son or daughter of one or two orixás, as if they belonged to these major forces and, at the same time, were constituted by them. It is not known the exact number of existing and worshipped orixás between Brazil and Africa, but in Brazil there is around 16 of them, among the most commonly venerated.

The first mask represented Oxóssi, the hunting god, who brings prosperity, abundance, and knowledge; the second belonged to Nanã the oldest female orixá related to creation of the world, earth, life and death, and wisdom; the third mask belonged to her son in the mythology, Obaluaê, the healer, also Lord of life and death; the fourth represented Yemanjá, the sea goddess, the great mother of everyone who, in the mythology, raised Obaluaê. Some of the Afro-Brazilian cults only worship orixás, and some include also ancestors such as Pretos Velhos (spirits of former African slaves full of wisdom and compassion) or native Indigenous peoples, the Caboclos. Some of them also worship other spiritual lineages such as children, gypsies, male and female guardians (Exu and Pombagira, respectively), mariners, cowboys, etc.

The masks at the bottom of the same picture are related to Umbanda and its variations, although they also worship orixás. The first mask presented Umbanda itself; the second represented the Pretos Velhos; the third mask showed Saint Jorge, a saint that has devotees in almost every Brazilian religion; the last mask had printed on the word Cambone; he/she is the helper of spirits when they incorporate in the mediums during rituals; cambones also assist the devotees in spiritual consultations; this mask could possibly be used in restricted rituals; besides protecting, it identifies a person's position, as if he/she wore a t-shirt informing "helper."

The Afro-Brazilian religious masks shown above were found in the virtual store Arte dos Orixás (Art of Orixás). Except for candles and candleholders, they did not sell ritual objects, but only objects to express someone's devotion: stamped mugs, glasses, plates, cushions, tiles, notebooks, bags, caps, t-shirts, and, lately, protection masks. I have picked a few to show here, but they have over 50 different religious motifs, including the whole pantheon of orixás, as well as other spiritual lineages already mentioned.

Michelle Gouvea Tomaz, ${ }^{2}$ the owner Arte dos Orixás, was devoted to a branch of Umbanda named Almas e Angola (Souls and Angola), present in Florianópolis, south

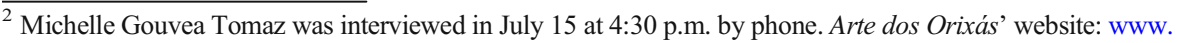
artedosorixas.com.br
} 
of Brazil, where she lived and had her company. She told the very spontaneous way on how religious decorated masks came up. At the very beginning of pandemic, the Mãede-Santo (priestess, literally mother-of-saint) of the Almas e Angola temple where Michelle attended was very afflicted due to the pandemic. The Mãe-de-Santo told Michelle: "I'm going to wear that Obaluaê's t-shirt you gave me. May He bless and protect us from this!" Then, Michelle gets the idea of making her Mãe-de-Santo a protection mask with Obaluaê's image printed on it. And so, she did it. When the natural daughter of the Mãe-de-Santo saw her with the Obaluaê adorned mask, she asked Michelle if she could make her a mask with Oxóssi's image printed on it. Then, the Mãe-de-Santo's husband asked her to make him a mask of his orixá. Michelle, then, showed some close friends, sisters and brothers in faith, through WhatsApp and Facebook the masks she had made. Two hours after posting, there were more than 80 people asking her to make masks of all orixás, saints, and other Umbanda icons. Michelle decided to include the protection masks in her product portfolio. From April, when the Ministry of Health approved fabric masks, up to the end of July, Michelle sold around 1.200 masks all over Brazil, mainly through her website. States of Bahia, Paraná, Rio de Janeiro, and São Paulo concentrated most of her clients. "We've been working overnight to meet the demand," said Michelle.

In both cases mentioned, the people who had the idea of making the masks did it spontaneously, just as did the people who wished to wear them; there was no direct interference of the "official" or institutional religion driving them to do it or not it. This is what Graham Harvey would possibly include into his idea of "religioning elsewhere"_- "religion may be or become visible in other places too" (2013: 32) - i.e., when actions that can be seen as religious are found out of officially religious space and/or time. Many of these actions could be considered religious not because they repeat the officially religious gestures and procedures, but because they reproduce religious aesthetic forms - that is, a disposition to do things as well as a taste, shaped by and within religious atmosphere - onto something else that had not been shaped by religion before. This example gives us an idea on how subjects and objects are shaped by religion on one hand and how they may input variations in its structures on the other.

\section{Making masks, making religion}

Not only masks with religious images materialized religion, but also regular masks made in the spirit of devotion and charity could be considered a material manifestation of religion as well. In Feira de Santana, northeast of Brazil, Catholic nuns of the Gruta do Rosário community have made protection masks to donate to hospitals and to those who help the poor. "This is a gesture of collaboration, the nuns are dedicating their lives, their time, putting a lot of effort and faith [...] The city of Feira de Santana has very generous people, they have endeavored, they have done their jobs and thanks to God we keep on going and making things up." Declared Dom Zanoni, Feira de Santana's archbishop (De olho na cidade 2020). The collective material, hand work, for a common greater cause, assumed as a way of saving lives, develops senses of hope and compassion. It also reinforces bonds among members of the group and helps devotees to keep their faith, maybe more effectively than a regular repetitive ritual; the pandemic certainly added extra emotional stimuli. As said in the quotation by Mohan 
and Wanier, to produce something real, ideas should be "attached to the devotee's body, emotions, practices and material culture" (Mohan and Warnier 2017: 374).

Another example on religious making masks was found in the Church of Jesus Christ of Latter-day Saints. Every year the church's program Hands that help saving lives engages in social and humanitarian actions counting on volunteers all over Brazil. This year, due to the pandemic, making masks was the call. They intend to produce 3 million masks in the clothing factory of their Distribution Center located in São Paulo, southeast of Brazil. "We have to help during this crisis. People's work here is loving our neighbors, assisting those who need the most. All safety procedures are being followed in the line of production," says Dante Parronchi, manager of the Distribution Center (Santos 2020). Possibly, this would be a very protestant way of materializing their faith, not through a devotional object, but through practical actions, reproducing a protestant habitus. Although there is no visual reference to their faith, cutting the fabric, sewing, adding the elastic, folding, and packing them within church's facilities (Distribution Center), in contact with brothers and sisters in faith for a common cause, doing something together may have felt as a "ritual." Such example could also be placed under Harvey's "religioning elsewhere" (2013), for the church's facilities not being an official place for ritual and for such activity also might not be considered officially religious. Nonetheless, these "particular modes through which imaginations materialize become manifest in public space, generating sensorial sensibilities and aptitudes that vest these imaginations with a sense of truth" (Meyer 2009: 6), materializing religion in an alternative way, whatever is possible during the pandemic. Plus, let us not forget that a sense of charity is also materialized, once all masks were donated.

\section{Conclusion}

The pandemic provided daily demonstrations on how Material Religions are. The changes in religions' traditional material aspects create new modes of making religion, consequently creating new modes of living. Material Religion approaches have never made so much sense - since senses of believers and researches all over the world have been challenged. The focus on doctrine and beliefs has made us ignore how materiality of religions act on us and specially how much we learn and have our bodies and perception conditioned by them. The increasing of religions practiced through new technologies and as well as non religious objetcs being decorated with religious symbols, demonstrated that when materiality is suppressed in one way, it comes around in another way, for we make the unreal real through materializing it through the body or in things. Therefore, in this sense, materiality seems to be intrinsically belonging to religion. In the case of those who wear masks adorned with religious motifs, faith becomes real through something attached to the body, reinforcing religious identity through visual stimulus brought by that particular icon; whether in the case of making masks together for donation, the feeling of being together and sharing esthetic aspects was more relevant. Further studies in Material Religion and COVID will prove that many of the changes caused by the pandemic will have occurred not because of 
the ideas it may have evoked but through the material changes it might have occasioned.

\section{List of sites that sell individual protection masks adorned with religious motifs Catholic}

Máscaras divertidas (virtual store for masks only. In the category "religious" one can find masks with catholic motifs).

https://www.mascarasdivertidas.com.br/mascaras-tecido-covid-estampas-religiosas

Clero Brasil. Arte sacra (virtual store for Catholics, also addressed to priests).

https://www.clerobrasil.com.br/loja/busca.php?loja=666632\&palavra_busca= mascaras

Mãe Maria. Arte litúrgica (virtual store for Catholics, also addressed to priests).

https://www.maemariaparamentos.com.br/produtos/kit-mascaras-de-protecao-07nossa-senhora-2-mascaras/

Ágape modas (virtual catholic fashion shop for devotees).

https://loja.agapemoda.com.br/mascara-de-protecao

Católicos na moda (virtual catholic fashion shop for devotees).

https://www.catolicosnamoda.com.br/mascara-de-protecao-adulto-amor-e-fe

Santa Surpresa (virtual catholic gift shop for devotees).

https://www.santasurpresa.com.br/produtos-devocionais/mascaras-de-protecaopersonalizadas-jesus $\% 2 \mathrm{D} \% 2 \mathrm{Dp}$

Elo 7 (virtual store for general goods, they carry catholic and afro-brazilian masks in the category "religious") https://www.elo7.com.br/lista/mascara-religiosa

Afro-Brazilian religions.

Sereya (virtual store for Afro-Brazilian religion's goods, addressed to devotees).

https://www.lojasereya.com.br/buscar?q=máscaras

Arte dos Orixás (virtual store for Afro-Brazilian religion's goods, addressed to devotees) https://www.artedosorixas.com.br/categorias/mascaras-de-protecao

\section{References}

Agência do Estado (2020) "Bolsonaro sanciona com vetos lei que obriga uso de máscaras." O Liberal. News reporting. July $3^{\text {rd }}$. Available at: https://iberal.com.br/brasil-e-mundo/brasil/bolsonaro-sanciona-comvetos-lei-que-obriga-uso-de-mascaras-1248171/. Accessed: 12/07/20

Bom Dia Piauí (2020) "Empresária fabrica máscaras com motivos religiosos durante o Mês de Maria em Teresina". Globoplay News reporting. May $7^{\text {th }}$. Available at: https://globoplay.globo.com/v/8537111/ Accessed: 28/05/20

De olho na cidade (2020) "Freiras produzem máscaras para doação a hospitais e população carente de Feira" News reporting. March 30 ${ }^{\text {th }}$. Available at: https://deolhonacidade.net/noticias/75749/freiras-produzemmascaras-para-doacao-a-hospitais-e-populacao-carente-de-feira.html . Accessed: 30/05/20

Fischler C (1988) Food, Self and Identity. Soc Sci Info J 27:275-293 Paris: Sage Publishing

Gell A (1998) The art and agency. An anthropological theory. Oxford University Press, Oxford

Globo Sociedade (2020) "Brasil tem 63.409 mortes por Covid-19, aponta consórcio de veículos de imprensa no boletim das $13 \mathrm{~h}$ ". News reporting. July $4^{\text {th }}$, 13:06. Available at: https://oglobo.globo.com/sociedade/ brasil-tem-63409-mortes-por-covid-19-aponta-consorcio-de-veiculos-de-imprensa-no-boletim-das-13h24515877. Accessed: 10/07/20

Harvey G (2013) Food, sex and strangers. Understanding religion as everyday life. Acumen Publishing Limited, Durham 
Levin J (2020) The faith community and the SARS-CoV-2 outbreak: part of the problem or part of the solution?". Springer. J Relig Health. https://doi.org/10.1007/s10943-020-01048-x

Machado, L (2020) "De cultos online a 'não leia notícias sobre pandemia': como as religiões estão lidando com o coronavírus no Brasil." BBC News Brasil. News reporting. Available at: https://noticias.uol.com.br/ saude/ultimasnoticias/bbc/2020/ 03/17/de-cultos-online-a-nao-leia-noticias-sobre-pandemia-como-asreligioes-estao-lidando-com-o-coronavirus-no-brasil.htm . Accessed: 20/05/20

Mauss, M (2006[1936]) "Techniques of the body." In: Schlanger N (ed.) Techniques, technology and civilisation. New York: Berghahn Books, 77-95

Meyer, B (org.) 2009. Aesthetic formations: media, religion and senses. New York: Palgrave MacMillan

Mohan U, Warnier J-P (2017) Marching the devotional subject: the bodily-and-material cultures of religion. $J$ Mater Cult 22(4):369-384

Morgan D (2010) Religion and material culture. The matter of belief. Routledge, New York

Pragmatismo Político (2020) "Coronavírus: Evangélicos fazem protesto e queimam objetos." News reporting. June $2^{\text {nd }}$. Available at: https://www.pragmatismopolitico.com.br/2020/06/coronavirus-evangelicos-fazemato-contra-mascaras-de-protecao-e-queimam-objetos.html

Roberts AF (2015) Masks. In: Plate BS (ed) Key Terms in Material Religion. Bloosmburry, London

Santos, C (2020). "Igreja convida voluntários para produzir e distribuir máscaras". Gazeta de Alagoas. News report. April $29^{\text {th }}$. Available at: https://d.gazetadealagoas.com.br/cidades/273394/igreja-convidavoluntarios-para-produzir-e-distribuir-mascaras

Terra notícias (2020) "Religiosos se unem a Bolsonaro e negam riscos da COVID-19." News reporting. April $2^{\text {nd }}$. Available at: https://www.terra.com.br/noticias/brasil/religiosos-se-unem-a-bolsonaro-e-negamriscos-da-covid-19,c6162ef99548c156c502776ed2af5739ji0jct26.html

Vasquez M (2011) More than belief. A materialist theory of religion. Oxford University Press, Oxford

Whitehouse H (2004) Modes of Religiosity. A cognitive theory of religious transmission. Altamira Press, New York

Wildman W, Bulbulia J, Sosis R, Schjoedt U (2020) Religion and the COVID-19 pandemic. Religion Brain Behav 10(2):115-117. https://doi.org/10.1080/2153599X.2020.1749339

Publisher's Note Springer Nature remains neutral with regard to jurisdictional claims in published maps and institutional affiliations. 